\title{
THE ANTIKETOGENIC ACTIVITY OF SUCCINIC ACID
}

\author{
By EATON M. MACKAY, JAMES W. SHERRILL, AND RICHARD H. BARNES \\ (From The Scripps Metabolic Clinic, La Jolla)
}

(Received for publication November 22, 1938)

Korányi and Szent-Györgyi have reported (1, 2) that relatively small doses of succinic acid would reduce or abolish the ketosis in diabetes. We have been unable to demonstrate this action of succinic acid. In Table I are presented three typical examples of the result of administering succinic acid to diabetic patients. All of these patients had been on their régime for some time and their diets were constant. They were given the free acid. The total ketone bodies in the

TABLE I

The influence of succinic acid on ketosis in diabetics upon a fixed régime

Urine excretion per day

\begin{tabular}{c|c|c|c|c}
\hline \hline Day & $\begin{array}{c}\text { Total ketone } \\
\text { bodies }\end{array}$ & Nitrogen & Glucose & $\begin{array}{c}\text { Succinic } \\
\text { acid per day }\end{array}$ \\
\hline grams & grams & grams & grams \\
\hline
\end{tabular}

Experiment 1*

\begin{tabular}{|c|c|c|c|}
\hline $\begin{array}{r}1 \\
2 \\
3 \\
4 \\
5 \\
6 \\
7 \\
8 \\
9 \\
10 \\
11 \\
12\end{array}$ & $\begin{array}{l}3.21 \\
4.50 \\
3.96 \\
4.22 \\
5.28 \\
4.12 \\
5.30 \\
4.20 \\
5.40 \\
2.10 \\
1.40 \\
0.09\end{array}$ & $\begin{array}{r}10.2 \\
13.4 \\
7.0 \\
7.9 \\
9.3 \\
12.5 \\
22.3 \\
18.4 \\
21.3 \\
3.2 \\
5.4 \\
1.1\end{array}$ & $\begin{array}{l}10 \\
10 \\
10 \\
10 \\
10\end{array}$ \\
\hline
\end{tabular}

Experiment $2 \dagger$

\begin{tabular}{|c|c|c|c|}
\hline $\begin{array}{l}1 \\
2 \\
3 \\
4 \\
5 \\
6 \\
7 \\
8 \\
9\end{array}$ & $\begin{array}{l}1.02 \\
0.88 \\
0.74 \\
1.10 \\
0.68 \\
1.30 \\
2.80 \\
2.10 \\
1.20\end{array}$ & $\begin{array}{r}3.2 \\
4.4 \\
4.8 \\
4.6 \\
3.2 \\
5.8 \\
20.2 \\
4.3 \\
2.2\end{array}$ & $\begin{array}{r}5 \\
5 \\
5 \\
5 \\
30\end{array}$ \\
\hline
\end{tabular}

* Experiment 1. Female, 48 years of age, weighing $\mathbf{5 4 . 5}$ $\mathrm{kgm}$. and receiving 24 units of insulin each day. The daily diet was composed of protein, 85 grams; fat, 145 grams; and carbohydrate, 120 grams. The dose of insulin was increased to 34 units on the tenth day.

$\dagger$ Experiment 2. Male, 26 years of age, weighing 75.6 $\mathrm{kgm}$. and receiving 30 units of insulin each day. The daily diet was composed of protein, 120 grams; fat, 170 grams; and carbohydrate, 200 grams. On the eighth and ninth days, 42 units of insulin were given.
TABLE I-Continued

\begin{tabular}{|c|c|c|c|c|}
\hline Day & $\begin{array}{c}\text { Total ketone } \\
\text { bodies }\end{array}$ & Nitrogen & Glucose & $\begin{array}{c}\text { Succinic } \\
\text { acid per day }\end{array}$ \\
\hline & grams & grams & grams & grams \\
\hline \multicolumn{5}{|c|}{ Experiment 3t } \\
\hline $\begin{array}{l}1 \\
2 \\
3 \\
4 \\
5 \\
6 \\
7 \\
8 \\
9\end{array}$ & $\begin{array}{l}2.81 \\
3.08 \\
0.68 \\
1.34 \\
2.56 \\
2.34 \\
1.71 \\
2.53 \\
2.07\end{array}$ & $\begin{array}{r}8.9 \\
7.1 \\
6.5 \\
10.9 \\
13.5 \\
9.7 \\
8.5 \\
8.4 \\
9.9\end{array}$ & $\begin{array}{r}8.2 \\
5.7 \\
8.6 \\
3.0 \\
33.9 \\
23.6 \\
5.6 \\
11.7 \\
13.0\end{array}$ & $\begin{array}{l}50 \\
15\end{array}$ \\
\hline
\end{tabular}

$\ddagger$ Experiment 3. Female, 17 years of age, weighing 41.3 $\mathrm{kgm}$. and receiving 28 units of insulin per day. The daily diet was composed of protein, 55 grams; fat, 140 grams; and carbohydrate, 150 grams.

urine were determined by Van Slyke's method (3), glucose according to Benedict (4), and total nitrogen by the macro-Kjeldahl (5). Small doses (Table I, Experiment 1) of succinic acid had no demonstrable effect upon the ketosis as measured by the ketonuria. This confirms the observations of several English investigators $(6,7)$. Larger doses of succinic acid had quite the opposite effect to the action claimed by Korányi and SzentGyörgyi. The ketonuria was actually increased (Table I, Experiments 2 and 3). In these cases the compound behaved in the same manner as might have been expected of glucose. This is hardly surprising for succinic acid is converted to glucose in the phloridzinized $\operatorname{dog}(8,9)$.

In the fasting normal human being the glucose effect of succinic acid is even more obvious (Table II). Contrary to its behavior in the diabetic, succinic acid is nitrogen sparing and has marked antiketogenic activity such as might be expected from an equivalent amount of glucose in a subject of this kind. The antiketogenic activity of succinic acid in the normal fasting organism may also be demonstrated in fasting rats in which a ketonuria has been induced by feeding the sodium salt of $\beta$-hydroxybutyric acid (Table III). If 
TABLE II

The influence of succinic acid upon the ketosis of a fasting normal subject*

\begin{tabular}{cllllll}
\hline Day & 1 & 2 & 3 & 4 & 5 & 6 \\
\hline
\end{tabular}

Total urine nitrogen, grams. 5.137 .006 .445 .124 .037 .91 Total ketone bodies, grams...2.17 $5.875 .962 .23 \quad 0.456 .70$ Succinic acid fed, grams..... $50 \quad 50$

* This individual was a female who was normal in every respect except for being slightly (5 to $10 \mathrm{kgm}$.) overweight. She was 38 years old and weighed $71 \mathrm{kgm}$. A general diet preceded the fast. While fasting, three cups of coffee without additions were allowed each day. The succinic acid was fed in dilute solution.

TABLE III

Antiketogenic action of succinic acid in fasting rats*

\begin{tabular}{|c|c|c|c|c|c|c|c|c|c|c|}
\hline \multirow{2}{*}{ Group } & \multirow{2}{*}{$\begin{array}{c}\text { Body } \\
\text { weight }\end{array}$} & \multirow{2}{*}{$\begin{array}{l}\text { Body } \\
\text { surface }\end{array}$} & \multicolumn{4}{|c|}{$\begin{array}{c}\text { Total nitrogen } \\
\text { excreted per rat } \\
\text { per day }\end{array}$} & \multicolumn{4}{|c|}{$\begin{array}{l}\text { Total ketone bodies } \\
\text { excreted per rat } \\
\text { per day }\end{array}$} \\
\hline & & & $\begin{array}{c}\text { Day } \\
1\end{array}$ & Day & $\mathrm{D}_{3}$ & $\underset{4}{\text { Day }}$ & Day $_{1}$ & Day & $\mathrm{D}_{3}$ & $\underset{4}{\text { Day }}$ \\
\hline $\begin{array}{l}\text { A } \\
\mathbf{B}\end{array}$ & $\begin{array}{c}\text { grams } \\
261 \\
256\end{array}$ & $\begin{array}{l}\text { sq.dcm. } \\
4.63 \\
4.56\end{array}$ & $\begin{array}{c}m g m \\
47 \\
41\end{array}$ & $\begin{array}{c}m g m \\
56 \\
45\end{array}$ & $\begin{array}{c}m g m \\
43 \\
35\end{array}$ & $\begin{array}{c}m g m \\
51 \\
39\end{array}$ & $\begin{array}{c}m g m \\
50 \\
15\end{array}$ & $\begin{array}{c}m g m \\
72 \\
13\end{array}$ & $\begin{array}{c}m g m \\
72 \\
13\end{array}$ & $\begin{array}{c}m g m . \\
74 \\
11\end{array}$ \\
\hline
\end{tabular}

* There were 10 male rats in each group which were fasted for a day before the experiment and throughout the experimental period. During the latter they were all given $1 \mathrm{cc}$. per sq.dcm. of body surface of a 6.3 per cent solution of racemic sodium $\beta$-hydroxybutyrate twice each day. The solution given to Group B contained 5.9 per cent of succinic acid in addition.

sufficient of the succinic acid is administered the ketonuria will completely disappear as may be seen in another experiment.

It is reasonable to assume that succinic acid is antiketogenic in the normal organism because it is converted to glucose. The relative activity of these compounds in this regard should throw some light upon this point. An excellent ketosis may be produced in rats if they are fasted after a period upon a diet low in choline and protein which results in a fatty liver $(10,11,12)$. When a high fluid intake is provided so as to insure large urine volumes the ketonuria becomes a good measure of the degree of ketosis. The ketosis increases to a maximum on about the third day of fasting and then tapers off. In comparing the antiketogenic action of the two compounds two millimols of succinic acid were fed for comparison with each millimol of glucose. This is the theoretical relation between these substances if three carbon atoms of succinic acid go to glucose (8), and under optimal conditions one millimol of glucose may be obtained from each two millimols of succinic acid fed to the phloridzinized dog (8, 9). Our results in Table IV show that succinic acid has essentially the same antiketogenic activity as an equivalent amount of glucose.

Substances which exhibit antiketogenic activity are generally, if not always, good glycogen formers $(13,14)$. Succinic acid is no exception. The results in Table $\mathrm{V}$ demonstrate that this compound is practically as good a glycogen former as is glucose.

\section{DISCUSSION}

We are unable to explain why we and others $(6,7)$ have been unable to corroborate in any degree the findings of Korányi and SzentGyörgyi concerning the desirable therapeutic effect of succinic acid in human diabetes in that the ketosis may be reduced or controlled by this compound. It is probable that their patients had not been adequately controlled before the study and were exhibiting the benefit of other therapeutic measures which had been showing their effects slowly when the succinic acid happened to be given. There is also, of course, the very remote possibility that if diabetics differ in the cause of their disturbed metabolism one type of case might be benefited by succinic acid, and it happened that the four patients treated by these authors were of this type.

Although not absolute proof, the fact that the antiketogenic activity of succinic acid is proportional to the glucose it may form is strong evidence that the antiketogenic action of succinic acid in the intact organism is simply a result of its conversion to glucose and is not due to any catalytic action on metabolism such as SzentGyörgyi and coworkers (15) and others (16) believe possible.

Our conclusion that in the normal organism succinic acid is as good an antiketogenic agent as an equivalent quantity of glucose is opposed to the conclusions of Deuel et al. (17) regarding the activity of this substance. A perusal of their data shows why they failed to obtain the same results. They fed sodium succinate. The succinic acid was oxidized leaving a substantial amount of alkali. Alkali is very ketogenic (18, 19) so that while their glucose-fed group had only the formation of ketones by the fasting fatty 
TABLE IV

The relative antiketogenic activity of succinic acid and glucose in fasting rats

\begin{tabular}{|c|c|c|c|c|c|c|c|c|c|c|c|c|c|c|}
\hline \multirow{3}{*}{ Group } & \multirow{3}{*}{ Sex } & \multirow{3}{*}{$\begin{array}{c}\text { Body } \\
\text { weight }\end{array}$} & \multirow{3}{*}{$\underset{\text { surface* }}{\text { Body }}$} & \multicolumn{8}{|c|}{ Excretion per sq.dcm. of body surface per day } & \multirow{2}{*}{\multicolumn{3}{|c|}{$\begin{array}{l}\text { Dose per sq.dcm. of body } \\
\text { surface per day }\end{array}$}} \\
\hline & & & & \multicolumn{4}{|c|}{ Total ketone bodies } & \multicolumn{4}{|c|}{ Total nitrogen } & & & \\
\hline & & & & $\underset{1}{\text { Day }}$ & $\underset{2}{\text { Day }}$ & $\underset{3}{\text { Day }}$ & $\underset{4}{\text { Day }}$ & $\underset{1}{\text { Day }}$ & $\underset{2}{\text { Day }}$ & $\underset{3}{\text { Day }}$ & $\underset{4}{\text { Day }}$ & $\mathrm{NaHCO}_{2}$ & Glucose & $\begin{array}{c}\text { Succinic } \\
\text { acid }\end{array}$ \\
\hline & & grams & sq.cm. & mgm. & mgm. & mgm. & mgm. & mgm. & mgm. & mgm. & mgm. & $m m$. & $m m$. & $m m$. \\
\hline
\end{tabular}

Experiment $1 \dagger$

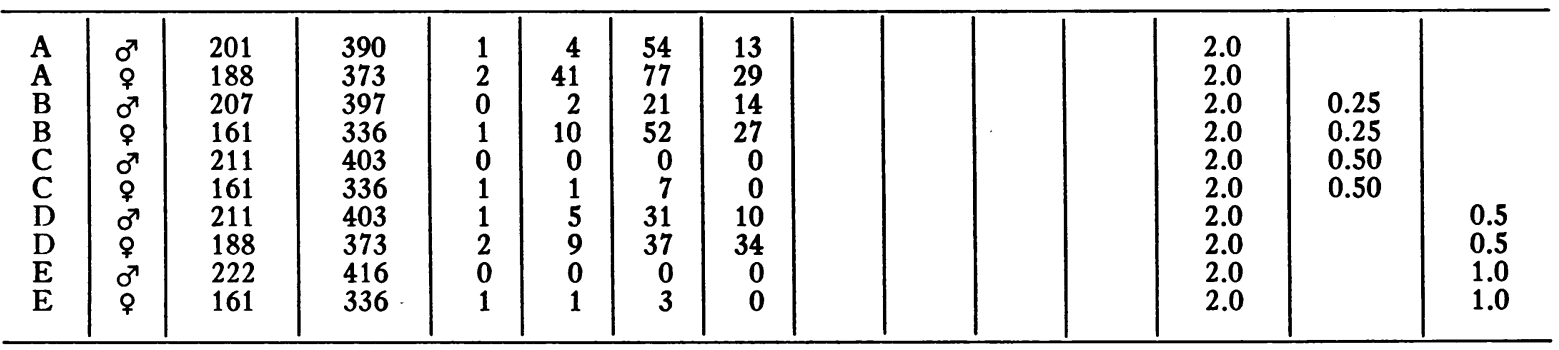

Experiment $2 \ddagger$

\begin{tabular}{|c|c|c|c|c|c|c|c|c|c|c|c|c|c|c|}
\hline $\begin{array}{l}\text { A } \\
\text { B } \\
\text { C } \\
\text { C } \\
\text { E }\end{array}$ & 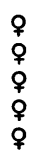 & $\begin{array}{l}167 \\
165 \\
165 \\
167 \\
166\end{array}$ & $\begin{array}{l}344 \\
340 \\
340 \\
344 \\
342\end{array}$ & $\begin{array}{r}46 \\
27 \\
5 \\
33 \\
9\end{array}$ & $\begin{array}{r}53 \\
19 \\
1 \\
26 \\
8\end{array}$ & $\begin{array}{r}36 \\
15 \\
0 \\
19 \\
1\end{array}$ & $\begin{array}{r}61 \\
16 \\
0 \\
22 \\
0\end{array}$ & $\begin{array}{l}22 \\
18 \\
15 \\
15 \\
16\end{array}$ & $\begin{array}{l}17 \\
14 \\
13 \\
15 \\
14\end{array}$ & $\begin{array}{l}16 \\
13 \\
14 \\
15 \\
14\end{array}$ & $\begin{array}{l}17 \\
18 \\
16 \\
15 \\
15\end{array}$ & $\begin{array}{l}2.0 \\
2.0 \\
2.0 \\
2.0 \\
2.0\end{array}$ & $\begin{array}{l}0.33 \\
0.67\end{array}$ & $\begin{array}{l}0.5 \\
1.0\end{array}$ \\
\hline
\end{tabular}

Experiment 38

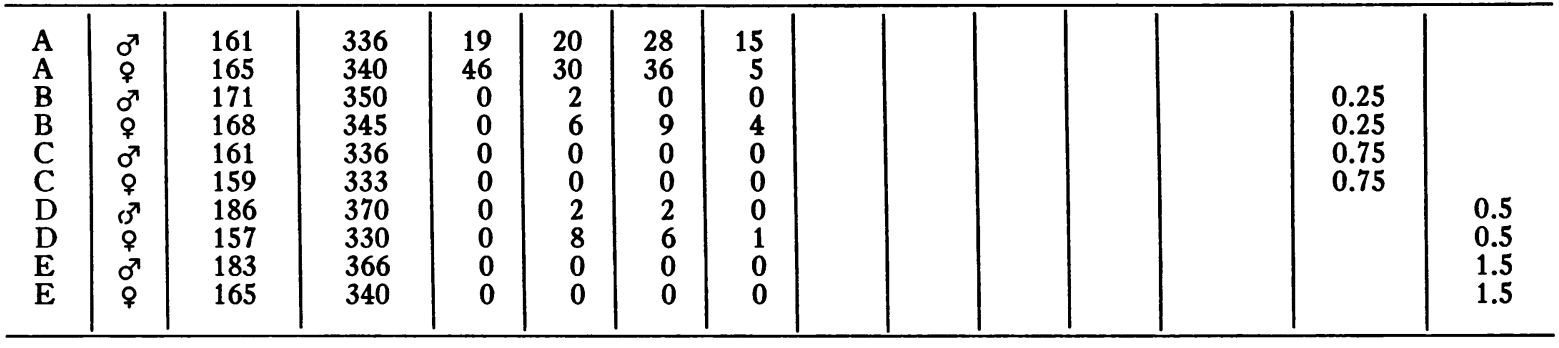

Experiment 4\|

\begin{tabular}{|c|c|c|c|c|c|c|c|c|c|c|c|c|c|c|}
\hline $\begin{array}{l}\text { A } \\
\text { A } \\
\text { B } \\
\text { B } \\
\text { C } \\
\text { C }\end{array}$ & 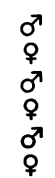 & $\begin{array}{l}151 \\
138 \\
157 \\
144 \\
150 \\
137\end{array}$ & $\begin{array}{l}322 \\
304 \\
330 \\
310 \\
321 \\
302\end{array}$ & $\begin{array}{l}4 \\
3 \\
0 \\
0 \\
0 \\
1\end{array}$ & $\begin{array}{r}10 \\
15 \\
0 \\
1 \\
2 \\
0\end{array}$ & $\begin{array}{r}8 \\
10 \\
1 \\
0 \\
0 \\
0\end{array}$ & $\begin{array}{l}6 \\
6 \\
0 \\
0 \\
0 \\
0\end{array}$ & $\begin{array}{l}27 \\
31 \\
22 \\
23 \\
33 \\
29\end{array}$ & $\begin{array}{l}24 \\
29 \\
27 \\
24 \\
29 \\
27\end{array}$ & $\begin{array}{l}23 \\
27 \\
26 \\
26 \\
26 \\
24\end{array}$ & $\begin{array}{l}19 \\
22 \\
18 \\
16 \\
21 \\
22\end{array}$ & $\begin{array}{l}2.5 \\
2.5 \\
2.5 \\
2.5 \\
2.5 \\
2.5\end{array}$ & $\begin{array}{l}0.25 \\
0.25\end{array}$ & $\begin{array}{l}0.5 \\
0.5\end{array}$ \\
\hline
\end{tabular}

*In all of these experiments "Body surface" was calculated from the formula (20) that we have generally used. The methods of urine collection and administering the various solutions have already been described $(22,23)$.

† Rats which had been on the low protein fatty liver producing diet (12) for 17 days were used. Urine collections were made and the various solutions administered beginning on the first day of fasting. There were 6 rats in each group, the averages for which are given here. The solutions were administered in two doses each day, the succinic acid in 2.95 and 5.90 per cent, the glucose in 2.25 and 4.50 per cent, and the $\mathrm{NaHCO}_{3}$ in 8.4 per cent solution

$\ddagger$ The rats had been on the special diet for 15 days. Collections were made on and after the second day of fasting. Due to an error in calculation (the incorrect assumption being made that all four carbon atoms of succinic acid form glucose) the glucose fed rats received more glucose than the equivalent of the succinic acid fed, and the antiketogenic action was consequently greater. The concentration in the solutions of succinic acid was 2.95 and 5.90 per cent, of glucose 3.0 and 6.0 per cent, and of $\mathrm{NaHCO}_{3} 8.4$ per cent. The results are averages for 5 rats in each group.

$\$$ In this experiment there were 5 rats in each group and they had been on the fatty liver producing diet for 17 days. Urine collections were commenced on the first day of fasting. The succinic acid solutions were not neutralized, nor was $\mathrm{NaHCO}_{3}$ fed to any of the other groups. All of the rats were given $1 \mathrm{cc}$. per sq.dcm. of body surface of 1 per cent $\mathrm{NaCl}$ twice each day and other substances administered were incorporated in this glucose, in 2.25 and 7.75 per cent and succinic acid in 2.95 and 9.84 per cent solution.

|| These rats were fasted directly from the stock diet, collections being commenced on the second day of fasting. The ketonuria is due solely to the alkalosis produced by the $\mathrm{NaHCO}_{3}$. This was fed in 10.5 per cent, the glucose in 2.25 per cent and the succinic acid in 2.95 per cent solutions. The results are averages for 6 rats in each group. 
TABLE V

Glycogenic activity of succinic acid and glucose in the albino rat*

\begin{tabular}{|c|c|c|c|c|c|c|c|c|c|c|}
\hline \multirow{2}{*}{ Group } & \multirow{2}{*}{$\begin{array}{c}\text { Body } \\
\text { weight }\end{array}$} & \multirow{2}{*}{$\begin{array}{c}\text { Body } \\
\text { surface }\end{array}$} & \multirow{2}{*}{$\begin{array}{c}\text { Liver } \\
\text { weight }\end{array}$} & \multicolumn{4}{|c|}{ Liver glycogen } & \multicolumn{3}{|c|}{$\begin{array}{l}\text { Amount fed per sq. } \\
\mathrm{cm} \text {. of body surface }\end{array}$} \\
\hline & & & & Minimum & Maximum & Average & Average & $\mathrm{NaHCO}_{3}$ & Glucose & $\begin{array}{l}\text { Succinic } \\
\text { acid }\end{array}$ \\
\hline & grams & $s q . d c m$. & grams & per cent & per cent & per cent & $\begin{array}{l}\text { mgm. per sq.cm. } \\
\text { of body surface }\end{array}$ & $m m$. & $m m$. & $m m$. \\
\hline $\begin{array}{l}\mathbf{A} \\
\mathbf{B} \\
\mathbf{C}\end{array}$ & $\begin{array}{l}150 \\
149 \\
150\end{array}$ & $\begin{array}{l}3.20 \\
3.18 \\
3.21\end{array}$ & $\begin{array}{l}4.12 \\
4.92 \\
4.82\end{array}$ & $\begin{array}{l}0.2 \\
7.1 \\
6.3\end{array}$ & $\begin{array}{r}0.8 \\
15.4 \\
12.9\end{array}$ & $\begin{array}{l}0.6 \\
9.6 \\
8.8\end{array}$ & $\begin{array}{r}8 \\
148 \\
138\end{array}$ & $\begin{array}{l}5.0 \\
5.0 \\
5.0\end{array}$ & 1.25 & 2.50 \\
\hline
\end{tabular}

* Each group was composed of 12 male rats. They were fasted for 24 hours and then given by stomach tube every 4 hours 1 cc. per sq.dcm. of body surface of the various solutions over a period of 20 hours, when they were anesthetized with nembutal and the liver glycogen determined (21). All of the solutions contained 8.4 per cent $\mathrm{NaHCO}_{3}$. In Group B there was 4.5 per cent glucose and in Group C 5.9 per cent succinic acid in addition.

liver rats to overcome, the group fed sodium succinate had in addition the ketogenic influence of the alkali to overcome. Experiment 4 in Table IV shows the effect on ketosis of alkali in the form of a dose of sodium bicarbonate comparable to the alkali involved in these experiments. When fasting from the stock diet without alkali administration there is no measurable ketonuria. Whenever we fed sodium succinate we naturally added an equivalent amount of sodium bicarbonate to the control and glucose-fed groups so that the observations in a given experiment would be comparable.

\section{SUM MARY}

Succinic acid has no antiketogenic activity in the human diabetic. In a normal fasting person it is as antiketogenic as an equivalent amount of glucose, to which succinic acid is converted in the phloridzinized and probably also in the normal organism.

The ketosis of fasting rats which previously had been receiving a fatty liver producing diet is reduced in the same degree by glucose as by an equivalent amount of succinic acid. These compounds are also almost equally good glycogen formers.

\section{BIBLIOGRAPHY}

1. Korányi, A., and v. Szent-Györgyi, A., Curing acidosis of diabetics by means of succinic acid treatment. Orvosi hetil., 1937, 81, 615. Cited from Chem. Abstr., 1937, 31, 6335.

2. Korányi, Andreas and v. Szent-Györgyi, Albert, Ueber die Bernsteinsäurebehandlung diabetischer Azidose. Deutsche med. Wchnschr., 1937, 63, 1029.
3. Van Slyke, D. D., Studies in acidosis. VII. The determination of $\beta$-hydroxybutyric acid, acetoacetic acid, and acetone in urine. J. Biol. Chem., 1917, 32, 455.

4. Benedict, S. R., The detection and estimation of glucose in urine. J. A. M. A., 1911, 57, 1193.

5. Peters, J. P., and Van Slyke, D. D., Quantitative Clinical Chemistry. Vol. II. Methods. Williams and Wilkins Co., Baltimore, 1932, p. 534.

6. Lawrence, R. D., McCance, R. A., and Archer, N., Clinical memoranda: Succinic acid treatment of diabetic ketosis. Brit. M. J., 1937, 2, 214.

7. Dunlop, D. M., and Arnott, W. M., Effect of succinic acid on diabetic ketosis. Lancet, 1937, 2, 738.

8. Ringer, A. I., Frankel, E. M., and Jonas, L., The chemistry of gluconeogenesis. IV. The fate of succinic, malic, and malonic acids in the diabetic organism, with consideration of the intermediary metabolism of aspartic and glutamic acids, proline, lysine, arginine, and ornithine. J. Biol. Chem., 1913, 14, 539.

9. MacKay, E. M., and Barnes, R. H., Conversion of succinic acid to glucose in the phloridzinized dog. Proc. Soc. Exper. Biol. and Med., 1938, 38, 417.

10. Best, C. H., and Channon, H. J., The action of choline and other substances in the prevention and cure of fatty livers. Biochem. J., 1935, 29, 2651.

11. Channon, H. J., and Wilkinson, H., Protein and the dietary production of fatty livers. Biochem. J., 1935, 29, 350.

12. MacKay, E. M., The influence of a pancreas extract ("fat metabolizing hormone") upon fat deposition in the liver on a low protein diet. Am. J. Physiol., 1937, 119, 783.

13. Shapiro, I., Studies on ketosis. V. The comparative glycogenic and ketolytic action of glucose and some carbohydrate intermediates. J. Biol. Chem., 1935, 108, 373.

14. Mirsky, I. A., Heiman, J. D., and Broh-Kahn, R. H., The antiketogenic action of glucose in the absence of insulin. Am. J. Physiol., 1937, 118, 290. 
15. Annau, E., Banga, I., Blazsó, A., Bruckner, V., Laki, K., Straub, F. B., and Szent-Györgyi, A., Ueber die Bedeutung der Fumarsäure für die tierische Gewebsatmung. Ztschr. f. physiol. Chem., 1936, 244, 105.

16. Krebs, H. A., The intermediate metabolism of carbohydrates. Lancet, 1937, 2, 736.

17. Deuel, H. J., Jr., Murray, S., and Hallman, L., A comparison of the ketolytic effect of succinic acid with glucose. Proc. Soc. Exper. Biol. and Med., 1937, 37, 413.

18. Beumer, H., and Soecknick, A., Ueber organische Acidose bei anorganischer Acidose und Alkalose. Ztschr. f. Kinderh., 1924, 37, 236.

19. Porges, O., and Lipschütz, H., Ueber Azetonurie und
Alkalose. Arch. f. exper. Path. u. Pharmakol., 1923, 97, 379.

20. Carman, G. G., and Mitchell, H. H., Estimation of the surface area of the white rat. Am. J. Physiol., 1926, 76, 380.

21. Good, C. A., Kramer, H., and Somogyi, M., The determination of glycogen. J. Biol. Chem., 1933, $100,485$.

22. MacKay, E. M., and Barnes, R. H., Influence of adrenalectomy on ketosis of fasting and on the action of the anterior pituitary ketogenic principle. Am. J. Physiol., 1937, 118, 184.

23. MacKay, E. M., and Barnes, R. H., Influence of adrenalectomy upon ketolytic activity. Am. J. Physiol., 1938, 122, 101. 